\title{
Oligodendroglioma occurring after radiation therapy for pituitary adenoma
}

\author{
CHUN-I HUANG, WEN-HSYANG CHIOU, DONALD M HO* \\ From the Department of Surgery (Neurosurgery) and Pathology, ${ }^{*}$ Veterans General Hospital, and National \\ Yang-Ming Medical College, Taipei, Taiwan
}

SUMMARY A 38 year old male dentist developed an oligodendroglioma of the left medial temporal lobe and parasellar region 12 years after radiotherapy with 6600 rads of acromegaly. The 30 cases of radiation-induced gliomas reported in the English literature are reviewed and analysed. The criteria for defining radiation-induced tumours of the central nervous system are proposed as follows: the tumour has a long quiescent "latency period", a location in the previously irradiated field, a verified histological difference from a primary condition, and does not arise from a primary condition associated with a genetic syndrome such as neurofibromatosis or tuberous sclerosis. The reported case fulfilled these criteria but appears to be the only reported radiation-induced oligodendroglioma.

The correlations between radiation and oncogenic effects have been studied in animal models, epidemiological analyses and case reports. Certain tumour types are more closely related to irradiation, especially thyroid and breast carcinoma, leukaemia, multiple myeloma, and various sarcomas. In the central nervous system (CNS), irradiation was not previously thought to be an oncogenic stimulus but more recently, evidence has shown that both benign and malignant intracranial tumours can develop after cranial irradiation. ${ }^{1}$ Most reports concern sarcoma and meningioma; ${ }^{23}$ radiation-induced gliomas were rarely documented ${ }^{4}$ but increasing numbers have been reported recently. This might be because patients with CNS tumours now live for longer after the effort of multimodal treatments. We review the 30 reported cases of radiation-induced glioma previously published in the English literature and add a further case of an oligodendroglioma. We also seek a correlation between the dose of irradiation and the latency before tumour development.

\section{Case report}

A 26 year old male who had just graduated from dental school was admitted to Veterans General Hospital, Taipei

Address for reprint requests: Chun-I Huang, M.D., Division of Neurosurgery, Department of Surgery, Veterans General Hospital, Taipei, Taiwan 11217.

Received 10 February 1987 and in revised form 20 April 1987. Accepted 27 May 1987 on 29 July, 1974, because of progressively enlarged hands and feet, and protruding mandible over the previous 6 years. Excessive thirst, polyuria, and headache had been experienced during the previous 3 months. On examination, enlargement of the jaw, thickening of the heel pads, and malocclusion of the temporo-mandibular joint were found. There were no cutaneous stigmata of neurofibromatosis. Plain radiographs of the skull showed an enlarged and deepened sella turcica, increased density and thickening of cranial bones, prognathism, and prominent frontal sinuses. Laboratory analysis detected hyperglycaemia. The serum level of growth hormone was not available at that time. The patient received cobalt- 60 radiotherapy with a total dose of 6600 rads in 33 fractions to the pituitary fossa through bitemporal ports ( 2400 rads in each side) and a frontal port (1800 rads). After discharge, the patient did well. Polyuria and polydipsia were much improved. Serum glucose levels returned to the normal range. The patient returned to his dental practice and there was no medical follow-up. In March 1986 after a 12 year quiescent period he began to experience lethargy and forgetfulness. There was a sudden onset of weakness of the right side limbs on 20 August 1986. A CT scan of the brain showed a mass in the medial temporal lobe and the parasellar and retrosellar regions, with calcification and possible haemorrhage (fig la). He was readmitted on 20 September when physical examination revealed acromegalic features, lethargy, decreased power in the right limbs, and disorientation. Laboratory tests showed a normal level of human growth hormone $(2.48 \mathrm{ng} / \mathrm{ml})$, and decreased levels of cortisol $(<2 \cdot 0 \mu \mathrm{g} / \mathrm{dl}$ at $7 \mathrm{am})$, testosterone $(<0.1 \mathrm{ng} / \mathrm{ml})$, T3 $(74.20 \mathrm{ng} / \mathrm{dl})$, and T4 $(4.67 \mathrm{ug} / \mathrm{dl})$. Free T4 $(0.82 \mathrm{ng} / \mathrm{dl})$ and TSH $(<1.25 \mathrm{uU} / \mathrm{ml})$ were within normal limits. There was a right homonymous hemianopia and optic atrophy. After replacement of steroid and thyroid hormones, the patient underwent a left 

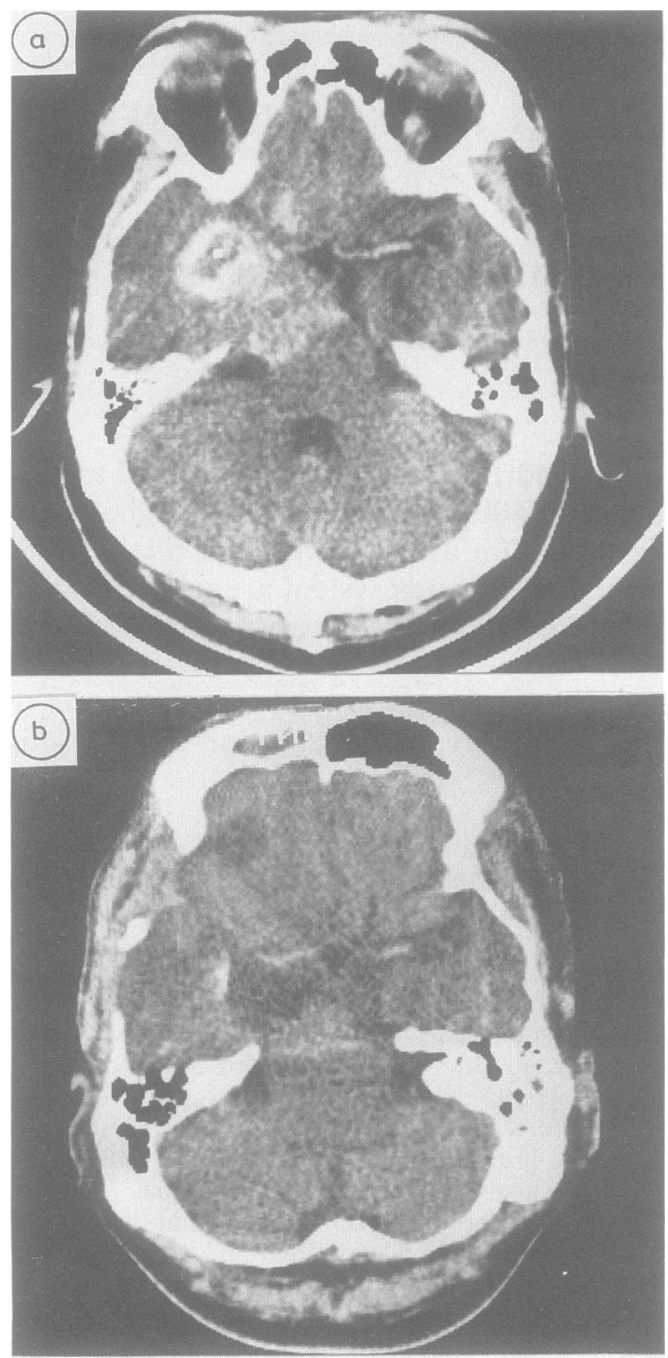

Fig 1 Contrast-enhanced CT scan of the brain, (a) preoperatively showing mass in the left medial temporal lobe, and the parasellar and retrosellar regions. with calcification and possible haemorrage. (b) postoperatively showing a much reduced mass-effect and little presence of residual tumour.

frontotemporal craniotomy with subtotal removal of tumour (fig 2) on 3 October 1986. The tumour was a highly cellular oligodendroglioma with compact collections of uniform cells. The nuclei were moderately pleomorphic and most of the tumour cells had a perinuclear halo or fried egg appearance (fig 3a). Although mitotic figures were few, some features of anaplastia were present in places with endothelial proliferation (fig $3 b$ ) and necrosis (fig 3c). Other than the oligodendroglia, there were no other neoplastic elements. Immunohistochemical staining for GFAP was negative except for occasional entrapped astrocytes. Because the patient had had a growth hormone secreting pituitary tumour, we also applied immunohistochemical staining for growth hormone and prolactin; all these stains were negative.

The patient's postoperative course was uncomplicated. He regained consciousness and normal mental status, but the right hemiparesis persisted. The postoperative CT scan showed a much smaller mass and little residual tumour (fig lb).

\section{Discussion}

Radiation therapy exerts its effect by ionisation which leads to the formation of pairs of free radical ions. ${ }^{5}$ These free radicals then react with normal cellular structures to cause cell death or damage. If it is the DNA in the chromatin of the target cell that is damaged, these cells may then acquire new phenotypic properties, which may eventually express themselves as a neoplasm. It is not surprising that a relationship between radiation and tumour does exist at the molecular level. ${ }^{6}$ Robinson ${ }^{7}$ has suggested that patients who receive cranial irradiation for a simple brain tumour are then at higher risk for developing a second intracranial neoplasm, in particular a meningioma. Although postradiation gliomas are rare in humans, 꿍 the experimental initiation of gliomas by radiation $\overrightarrow{\overrightarrow{0}} \overrightarrow{0}$ has been shown in monkeys and rats. ${ }^{8-10}$ The inability to establish a link between neoplastic cellular alter- $\stackrel{\odot}{\circ}$ ations after previous radiation makes the diagnosiso extremely controversial in clinical cases. Cahan et al ${ }^{11} \cap$ proposed four criteria for post-radiation osteogenic sarcoma and these have been generally accepted. After modifying the criteria slightly, we suggest that the most important requirements for radiation-induced tumours of CNS should be as follows: The tumour must have (1) a long latency period sufficient to indicate that the lesion was not already present at the time of irradiation, (2) a location in the previously irra-

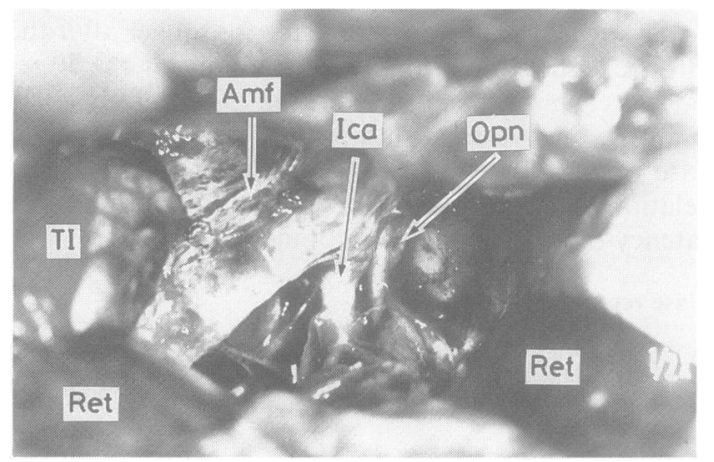

Fig 2 Operative findings after subtotal removal of tumour through left fronto-temporal craniotomy. T1: Temporal lobe, Ret: Retractor, Opn: Optic nerve, Ica: Internal carotid artery, Amf: Anterior middle fossa. 

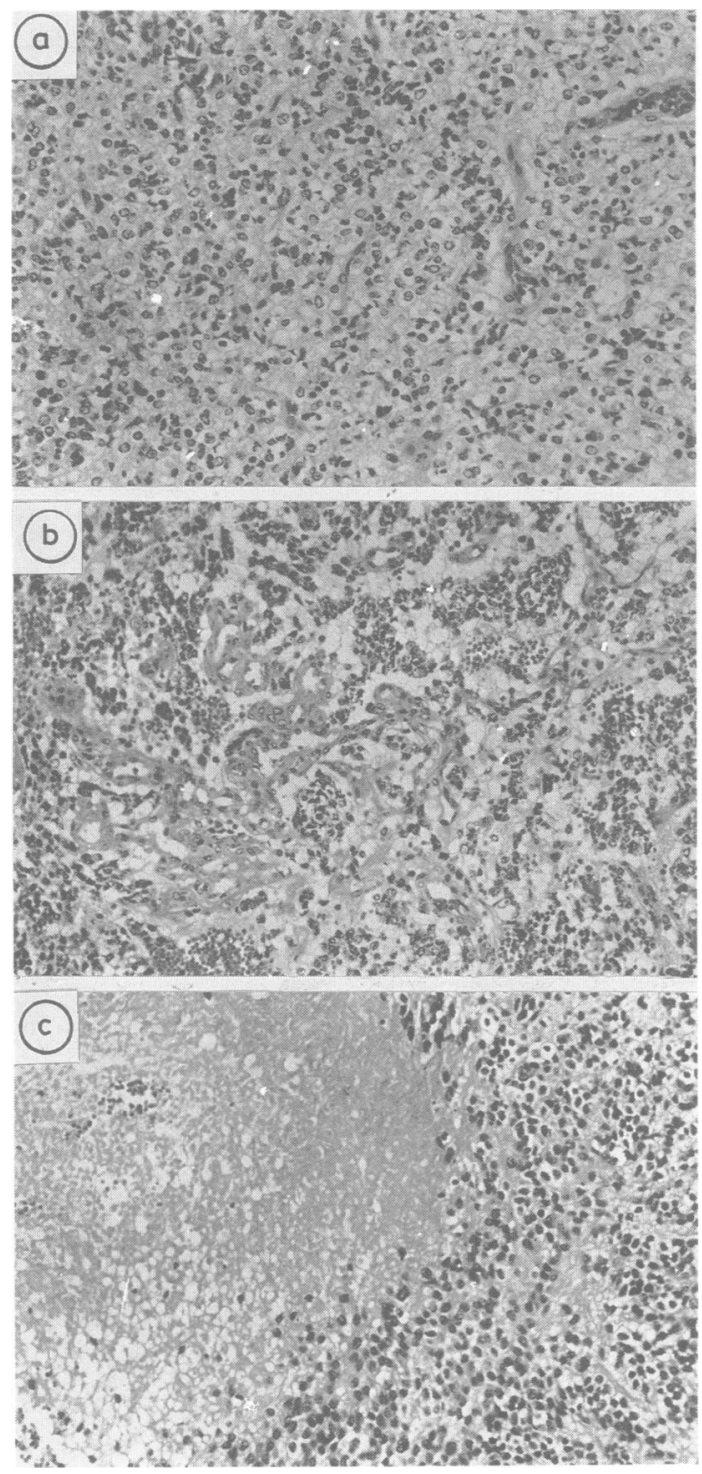

Fig 3 (a) Oligodendroglioma showing fried-egg appearance of the tumour cells. (H\&E, $\times 200,(b)$ Oligodendroglioma with endothelial proliferation. ( $H \& E$, $\times 160)$, (c) Oligodendroglioma with necrosis. (H\&E, $\times 150)$.

diated field, (3) a verified histological difference from the primary condition, and (4) an origin not recognised to be associated with a primary defined genetic syndrome such as neurofibromatosis or tuberous sclerosis. Because the phakomatoses are associated with an increased incidence of multiple tumours of both similar and differing histology, ${ }^{12} 13$ it is more logical, to include the fourth criterion for defining a radiation-induced tumour.

In our case, although there was no histological verification of the primary tumour, an enlarged and deepened sella turcica in an acromegalic patient supports the diagnosis of a growth hormone secreting pituitary adenoma. Furthermore, the long latency period excluded the possibility that an anaplastic oligodendroglioma was present in this location before irradiation. A genetic factor, as in neurofibromatosis or tuberous sclerosis was not present in our patient. Therefore, our case fulfilled our four criteria.

We reviewed and analysed the 31 reported cases of radiation-induced glioma (including our present case) (table 1). ${ }^{74-36}$ The ratio of male to female is 20:10, with an average age of 13.9 years. The radiation dose ranged from 150 to 6600 rads, with an average latency period of 11.5 years. Most of these patients were young when first irradiated. The second tumour developed at a younger average age ( 25 to 35 years) compared with the age ( 40 to 50 years) when naturally occurring tumours are expected within the general population. A long latency period (an average of 11 years) is needed for second tumours to occur, which may explain why most of the reported cases are in the younger age group. That radiation induced oncogenesis is stronger during tissue maturation may be another factor. ${ }^{5}$ The male preponderance ${ }^{81837}$ is unexplained. The latency of radiation-induced gliomas and sarcomas has been compared with that of other cranial and intracranial tumours induced by radiation. We found that the average latency of reported radiation-induced gliomas and sarcomas has been around 11 years. Meningiomas have had even longer latencies (around 26 years). This discrepancy may be due to the histological behaviour of postradiation tumours. The more benign lesions seem to occur after a longer latency period. Iacoco et al, ${ }^{38}$ who reviewed 35 patients with postradiation meningiomas, indicated that the average latency in the low-doseirradiated group (less than 800 rads) was 31.3 years, whereas in the high-dose group it was 20.8 years. These data suggest that the higher the dose of irradiation, the shorter the latency period. However, there was not a correlation between dose and latency in our analyses of 31 cases of radiation-induced gliomas (table 2). We also did not find a correlation between latency and the type of the secondary tumour (table 3). Table 4 shows that a statistically significant difference did exist between the latency of primary haemopoietic system (HS) neoplasia (5.5 years), and that of primary non HS neoplasia (16.1 years). An increased risk of developing a malignant tumour has been noted in patients with congenital immunodeficiency. ${ }^{39}$ The weaker immunity present in patients with HS neoplasia may be the explanation. 
Table 1 Summary of radiation-induced gliomas in 31 cases

\begin{tabular}{|c|c|c|c|c|c|c|c|c|c|}
\hline $\begin{array}{l}\text { Case } \\
\text { No. }\end{array}$ & Primary condition & $\begin{array}{l}\text { Age at } \\
R / T(y r)\end{array}$ & Sex & $\begin{array}{l}\text { Dose } \\
\text { (rads) }\end{array}$ & $\begin{array}{l}\text { Latency } \\
(y r)\end{array}$ & $\begin{array}{l}\text { Type of } \\
\text { glioma }\end{array}$ & $\begin{array}{l}\text { Location of } \\
\text { second tumour }\end{array}$ & $\begin{array}{l}\text { First Author } \\
\text { and reference }\end{array}$ & $\begin{array}{l}\text { Publis } \\
\text { Year }\end{array}$ \\
\hline $\begin{array}{l}1 \\
2 \\
3 \\
4 \\
5 \\
6\end{array}$ & $\begin{array}{l}\text { Meningioma } \\
\text { Cervical adenitis } \\
\text { Tinea capitis } \\
\text { Tinea capitis } \\
\text { Craniopharyngioma } \\
\text { Craniopharyngioma }\end{array}$ & $\begin{array}{r}? \\
11 \\
4 \\
10 \\
22 \\
9\end{array}$ & $\begin{array}{l}\mathbf{M} \\
\mathbf{M} \\
\mathbf{M} \\
\mathbf{M} \\
\mathbf{M} \\
\mathbf{F}\end{array}$ & $\begin{array}{l}4000 \\
400 \\
500-800 \\
500-800 \\
5400 \\
6007\end{array}$ & $\begin{array}{r}10 \\
11 \\
4 \\
1 \\
6 \\
5\end{array}$ & $\begin{array}{l}\text { Astrocytoma } \\
\text { Glioblastoma } \\
\text { Astrocytoma } \\
\text { Astrocytoma } \\
\text { Glioblastoma } \\
\text { Anaplastic } \\
\quad \text { Astrocytoma }\end{array}$ & $\begin{array}{l}\text { Cerebrum } \\
\text { Cerebrum } \\
\text { Optic chiasm } \\
\text { Not given } \\
\text { Cerebrum } \\
\text { Cerebrum }\end{array}$ & $\begin{array}{l}\text { Jones (14) } \\
\text { Saenger (15) } \\
\text { Albert (16) } \\
\text { Albert (16) } \\
\text { Komaki (17) } \\
\text { Sogg (18) }\end{array}$ & $\begin{array}{l}1960 \\
1960 \\
1966 \\
1966 \\
1977 \\
1978\end{array}$ \\
\hline 7 & Medulloblastoma & 12 & $\mathbf{M}$ & 5000 & 11 & $\begin{array}{l}\text { Anaplastic } \\
\text { Astrocytoma }\end{array}$ & Cerebrum & Kleriga (19) & 1978 \\
\hline $\begin{array}{r}8 \\
9 \\
10 \\
11 \\
12\end{array}$ & $\begin{array}{l}\text { Pineal teratoma } \\
\text { Meningioma } \\
\text { Histiocytosis } \\
\text { Ependymoma } \\
\text { Glomus jugulare tumour }\end{array}$ & $\begin{array}{l}10 \\
36 \\
9 \text { Months } \\
1 \\
44\end{array}$ & $\begin{array}{l}\mathbf{M} \\
\mathbf{M} \\
? \\
\mathbf{F} \\
\mathbf{M}\end{array}$ & $\begin{array}{r}4000 \\
2750 \\
600 \\
3960 \\
4480\end{array}$ & $\begin{array}{r}26 \\
21 \\
15 \\
5 \\
8\end{array}$ & $\begin{array}{l}\text { Glioblastoma } \\
\text { Glioblastoma } \\
\text { Ependymoma } \\
\text { Glioblastoma } \\
\text { Anaplastic } \\
\quad \text { Astrocytoma }\end{array}$ & $\begin{array}{l}\text { Cerebrum } \\
\text { Cerebrum } \\
\text { 4th ventricle } \\
\text { Cerebrum } \\
\text { Cerebrum }\end{array}$ & $\begin{array}{l}\text { Robinson (7) } \\
\text { Robinson (7) } \\
\text { Haselow (20) } \\
\text { Bachman (21) } \\
\text { Pressig (22) }\end{array}$ & $\begin{array}{l}1978 \\
1978 \\
1978 \\
1978 \\
1979\end{array}$ \\
\hline $\begin{array}{l}13 \\
14 \\
15 \\
16 \\
17 \\
18 \\
19 \\
20\end{array}$ & $\begin{array}{l}\text { Craniopharyngioma } \\
\text { Pulmonary TB } \\
\text { Hodgkin's disease } \\
\text { Ac. lymphocytic leukaemia } \\
\text { Medulloblastoma } \\
\text { Medulloblastoma } \\
\text { Choriocarcinoma } \\
\text { Ac. lymphoblastic } \\
\text { leukaemia }\end{array}$ & $\begin{array}{r}4 \\
20 \\
21 \\
2 \\
5 \\
4 \\
17 \\
4\end{array}$ & $\begin{array}{l}\mathbf{F} \\
\mathbf{F} \\
\mathbf{M} \\
\mathbf{M} \\
\mathbf{M} \\
\mathbf{F} \\
\mathbf{F} \\
\mathbf{F}\end{array}$ & $\begin{array}{r}6000 \\
150 \\
4969 \\
2400 \\
3000 \\
3500 \\
4000 \\
2400\end{array}$ & $\begin{array}{r}8 \\
25 \\
6 \\
5 \\
13 \\
16 \\
6 \\
5\end{array}$ & $\begin{array}{l}\text { Glioblastoma } \\
\text { Astrocytoma } \\
\text { Glioblastoma } \\
\text { Glioblastoma } \\
\text { Glioblastoma } \\
\text { Astrocytoma } \\
\text { Glioblastoma } \\
\text { Glioblastoma }\end{array}$ & $\begin{array}{l}\text { Cerebrum } \\
\text { Spinal cord } \\
\text { Spinal cord } \\
\text { Cerebrum } \\
\text { Cerebrum } \\
\text { Cerebrum } \\
\text { Cerebrum } \\
\text { Cerebrum }\end{array}$ & $\begin{array}{l}\text { Gutjahr (23) } \\
\text { Steinbok (24) } \\
\text { Clifton (25) } \\
\text { Chung (26) } \\
\text { Pearl (27) } \\
\text { Cohen (28) } \\
\text { Barnes (29) } \\
\text { Sanders (30) }\end{array}$ & $\begin{array}{l}1979 \\
1980 \\
1980 \\
1980 \\
1980 \\
1981 \\
1982 \\
1982\end{array}$ \\
\hline $\begin{array}{l}21 \\
22 \\
23\end{array}$ & $\begin{array}{l}\text { Pituitary adenoma } \\
\text { Pituitary adenoma } \\
\text { Ac. lymphoblastic } \\
\text { leukaemia }\end{array}$ & $\begin{array}{r}38 \\
25 \\
3\end{array}$ & $\begin{array}{l}\mathbf{M} \\
\mathbf{M} \\
\mathbf{F}\end{array}$ & $\begin{array}{l}7900 \\
4500 \\
2400\end{array}$ & $\begin{array}{r}14 \\
10 \\
5\end{array}$ & $\begin{array}{l}\text { Glioblastoma } \\
\text { Glioblastoma } \\
\text { Astrocytoma }\end{array}$ & $\begin{array}{l}\text { Cerebrum } \\
\text { Cerebrum } \\
\text { Cerebrum }\end{array}$ & $\begin{array}{l}\text { Piatt (31) } \\
\text { Piatt (31) } \\
\text { Anderson (32) }\end{array}$ & $\begin{array}{l}1983 \\
1983 \\
1984\end{array}$ \\
\hline $\begin{array}{l}24 \\
25 \\
26 \\
27 \\
28 \\
29\end{array}$ & $\begin{array}{l}\text { Scalp haemangioma } \\
\text { Craniopharyngioma } \\
\text { Anaplastic ependymoma } \\
\text { Retinoblastoma } \\
\text { Burkitt's lymphoma } \\
\text { Ac. lymphocytic leukaemia }\end{array}$ & $\begin{array}{l}24 \\
11 \\
2 \\
2 \text { weeks } \\
5 \\
13\end{array}$ & $\begin{array}{l}\mathbf{F} \\
\mathbf{M} \\
\mathbf{M} \\
\mathbf{M} \\
\mathbf{M} \\
\mathrm{F}\end{array}$ & $\begin{array}{l}1610 \\
5900 \\
3500 \\
5500 \\
1800 \\
2400\end{array}$ & $\begin{array}{r}15 \\
25 \\
14 \\
12 \\
5 \\
7\end{array}$ & $\begin{array}{l}\text { Astrocytoma } \\
\text { Glioblastoma } \\
\text { Glioblastoma } \\
\text { Glioblastoma } \\
\text { Glioblastoma } \\
\text { Anaplastic } \\
\text { Astrocytoma }\end{array}$ & $\begin{array}{l}\text { Cerebrum } \\
\text { Cerebrum } \\
\text { Cerebrum } \\
\text { Cerebrum } \\
\text { Cerebrum } \\
\text { Cerebellum }\end{array}$ & $\begin{array}{l}\text { Zochodne (33) } \\
\text { Liwnicz (34) } \\
\text { Liwnicz (34) } \\
\text { Liwnicz (34) } \\
\text { Liwnicz (34) } \\
\text { Raffel (35) }\end{array}$ & $\begin{array}{l}1984 \\
1985 \\
19850 \\
19850 \\
19850 \\
19850\end{array}$ \\
\hline $\begin{array}{l}30 \\
31\end{array}$ & $\begin{array}{l}\text { Meningioma } \\
\text { Pituitary Adenoma } \\
\quad \text { (present case) }\end{array}$ & $\begin{array}{l}32 \\
26\end{array}$ & $\begin{array}{l}\mathbf{M} \\
\mathbf{M}\end{array}$ & $\begin{array}{l}5600 \\
6600\end{array}$ & $\begin{array}{l}10 \\
12\end{array}$ & $\begin{array}{l}\text { Glioblastoma } \\
\text { Anaplastic } \\
\text { Oligodendro- } \\
\text { glioma }\end{array}$ & $\begin{array}{l}\text { Cerebrum } \\
\text { Cerebrum }\end{array}$ & $\begin{array}{l}\text { Zuccarello (36) } \\
\text { Huang }\end{array}$ & $\begin{array}{r}1986< \\
19870 \\
\text { 음 }\end{array}$ \\
\hline
\end{tabular}

$\mathrm{R} / \mathrm{T}$ : Radiotherapy.

Ac: Acute.

Multiple gliomas have been described in the literature and, according to Batzderf and Malamud, ${ }^{40}$ account for $2 \cdot 4 \%$ of all gliomas. Multiple primary brain tumours of different histological types are encountered rather less frequently. According to the report of Deen and Laws, most of them belong to meningioma-glioma combinations. ${ }^{41}$ It has been suggested that the "irritative effect" of a low grade glioma will induce the development of a secondary meningeal tumour; vice versa, a meningioma could induce malignant transformation in the underlying brain parenchyma. ${ }^{37}$ Our case is a pituitary

Table 2 Relationship between dose and latency in 31 patients

\begin{tabular}{lcl}
\hline Dosage (rads) & No. of cases & Latency (average, yr) \\
\hline Low $(<$ or $=800)$ & 5 & $11 \cdot 2$ \\
High $(>800)$ & 26 & $10 \cdot 8$ \\
\hline
\end{tabular}

Table 3 Relationship between pathological type of second tumour and latency

\begin{tabular}{lcc}
\hline Type & No. of cases & Latency (average, yr) \\
\hline Astrocytoma & 7 & $10 \cdot 9$ \\
Anaplastic astrocytoma & 4 & $7 \cdot 8$ \\
Glioblastoma & 18 & $11 \cdot 2$ \\
Ependymoma & 1 & $15 \cdot 0$ \\
Anaplastic & 1 & $12 \cdot 0$ \\
$\quad$ oligodendroglioma & 31 & $11 \cdot 5$ \\
\hline
\end{tabular}

Table 4 Latency between primary $H S^{*}$ neoplasia and Non HS neoplasia

\begin{tabular}{lccl}
\hline Group & Total No. & $\begin{array}{l}\text { Case No. } \\
\text { in table } 1\end{array}$ & $\begin{array}{l}\text { Latency } \\
\text { (Average, yr) }\end{array}$ \\
\hline $\begin{array}{l}\text { Primary } \\
\text { HS neoplasia }\end{array}$ & 6 & $\begin{array}{c}15,16,20,23, \\
28,29\end{array}$ & $5 \cdot 5$ \\
$\begin{array}{c}\text { Primary } \\
\text { Non HS neoplasia }\end{array}$ & 25 & $\begin{array}{c}21-22,24-27, \\
30-31\end{array}$ & $16 \cdot 1$ \\
\hline
\end{tabular}

*HS: haemopoietic system. 
adenoma-oligodendroglioma combination and an "irritative effect" can not have had any role.

It has been suggested also that the presence of gliosis in brain tissue increases the chance of induction of a glioma by radiation. ${ }^{12}{ }^{18}$ Based on our case and our review of the literature it appears that in many cases the initial disease was not likely to be accompanied by gliosis. Thus, the presence of prominent gliosis is not essential for radiation induction of gliomas.

We found reports of only two cases of a glioma occurring in a patient who had received CNS irradiation for pituitary adenoma. ${ }^{31}$ We report another case, in which the pathological type was an oligodendroglioma. It is not known why the same primary tumours, such as pituitary adenoma, can develop radiation-induced tumours of different cell types, such as fibrosarcomas, meningiomas or gliomas. From the relatively few reported cases, it is impossible to say for certain if the radiation played a singularly important role in the development of the new tumour or if some underlying or predisposing factors also contributed. Further studies and more data are necessary to elucidate this.

The benefit of postoperative radiation therapy for incompletely resected pituitary adenoma is well documented. The risk of inducing a second tumour should be considered, especially when radiation is used as a primary therapy for a functioning pituitary adenoma, as is suggested by our case report.

\section{References}

1 United Nations scientific committee on the Effects of Atomic Radiation: Sources and Effects of Ionizing Radiation. 1977 report to General Assembly, with annexes. New York, United Nations Publications, 1977.

2 Modan B. Baidatz D, Mart H, Steinitz R, Levin SG. Radiationinduced head and neck tumours. Lancet 1974;i:277-9.

3 Noetzli M, Malamud N. Postirradiation fibrosarcoma of the brain. Cancer 1962:15:617-22.

4 United Nations Scientific Committee on the Effects of Atomic Radiation Report. General Assembly Official Records, New York, United Nations, 1969, 24th session, suppl 13(A/7613):76-77.

5 Fajardo LF. Pathology of Radiation Injury. New York. Masson Inc. 1982:252-5.

6 Vanankeran SC, Whelers KT. Relationship between the repair of radiation-induced DNA damage and recovery from potentially lethal damage in $9 \mathrm{~L}$ rat brain tumor cells. Cancer Res 1984:44:1091-7.

7 Robinson RG. A second brain tumor and irradiation. J Neurol Neurosurg Psychiatry 1978;41:1005-12.

8 Castanera TJ, Tones DC, Kimeldorf DJ, Rosen VJ. The influence of whole body exposure to X-rays or neutrons on the life span distribution of tumors among male rats. Cancer Res 1968;28:170-82.

9 Kent SP. Pickering JE. Neoplasms in monkeys (Macaca mulat) spontaneous and irradiation-induced. Cancer 1958;11:138-47.

10 Haymaker W, Rubinstein LJ, Miquel J. Brain tumors in irradiated monkeys. Acta Neuropathol (Berl) 1972;20:267-77.

11 Cahan WG. Woodard HQ, Higinbothan NL, Stewart FW, Coley BL. Sarcoma arising in irradiated bone: Report of 11 cases.
'Cancer 1948;1:3-29.

12 Rubinstein LJ. Tumors of the Central Nervous System (Atlas of Tumor Pathology, 2nd series fascicle 6). Washington DC, Armed Forces Institute of Pathology, 1972.

13 Courville CB. Multiple primary tumors of the brain: Reviews of the literature and report of 21 cases. Am J Cancer 1936;26:703-31.

14 Jones A. Supervoltage X-ray therapy of intracranial tumors. Ann $R$ Col Surg Engl 1960;27:310-54.

15 Saenger EL, Silverman FN, Sterling T, Turner ME. Neoplasia following therapeutic irradiation for benign condition in childhood. Radiology 1960;74:889-904.

16 Albert RE, Omran AR, Brauen EW, et al. Follow-up study of patients treated by X-ray for tinea capitis. Am J Publ Health 1966;56:2114-20.

17 Komaki S, Komaki R, Choi H, Correa-paz F. Radiation and drug induced intracranial neoplasm with angiographic demonstration. Neurol Med Chir (Tokyo) 1977;17:55-62.

18 Sogg RL, Donaldson SS, Yorke CH. Malignant astrocytoma following radiotherapy of a craniopharyngioma. J Neurosurg 1978;48:622-7.

19 Kleriga E, Sher JH, Nallainathan SK, Syein SC, Sacher M. Development of cerebellar malignant astrocytoma at site of medulloblastoma treated 11 years earlier. $J$ Neurosurg 1978;49:445-9.

20 Haselow RE, Nesbit M, Dehner LP, Hkan FM, Mchugh R, Levitt $\mathrm{SH}$. Second neoplasms following megavoltage radiation in a pediatric population. Cancer 1978;42:1185-91.

21 Bachman DS, Ostrow PT. Fatal long-term sequela following radiation "cure" for ependymoma. Ann Neurol 1978;4:319-21.

22 Pressig SH, Bohmfalk GL, Reichel GW, Smith MT. Anaplastic astrocytoma following radiation for a glomus jugulare tumor. Cancer 1979;43:2243-7.

23 Gutjahr P, Dieterich E. Risiko zweiter maligner Neoplasian nach erfolgreicher Tumorbehandlung in Kidnersalter. Deutch Med Wochenshr 1979;104:969-72.

24 Steinbok P, Spinal cord glioma after multiple fluoroscopies during artificial pneumothorax treatment of pulmonary tuberculosis. J Neurosurg 1980;52:838-41.

25 Clifton MD, Amromim GD, Perry MC, Abadir R, Watt SC, Levy N. Spinal cord glioma following irradiation for Hodgkin's disease. Cancer 1980;45:2051-5.

26 Chung CK, Stryker JA, Cruse R, Vanucci R, Towfigi J. Glioblastoma multiforme following prophylactic cranial irradiation and intrathecal methotrexate in a child with acute lymphocytic leukemia. Cancer 1981;47:2563-6.

27 Pearl GS, Mirra SS, Miles ML. Glioblastoma multiforme occurring 13 years after treatment of a medulloblastoma. Neurosurgery 1980;6:546-551.

28 Cohen MS, Kushner MJ, Dell S. Frontal lobe astrocytoma following radiotherapy for medulloblastoma. Neurology 1981;31:616-9.

29 Barnes AE, Liwnicz BH, Schellhas HF, Altshuller G, Aron BS, Lippert WA. Successful treatment of placental choriocarcinoma metastatic to brain followed by primary brain glioblastoma. Gynecol Oncol 1982;13:108-14.

30 Sanders J, Sale GE, Ramberg R, Clift R, Buckner CD, Thomas ED. Glioblastoma multiforme in a patient with acute lymphoblastic leukemia who received a marrow transplantation. Transplant Proc 1982;14:770-4.

31 Piatt JH, Blue JM, Schold SC, Barger PC. Glioblastoma multiforme after radiotherapy for acromegaly. Neurosurgery 1983;13:85-9.

32 Anderson JR, Treip CS. Radiation-induced intracranial neoplasms: a report of three possible cases. Cancer 1984;53:426-9.

33 Zochodne DW, Cairncross JG, Arce FP, et al. Astrocytoma following scalp radiotherapy in infant. Can $J$ Neurol Sci 1984;11:475-8.

34 Liwnicz BH, Berger TS, Liwnicz RG, Aron BS. Radiationassociated gliomas: A report of four cases and analysis of 
postradiation tumors of the central nervous system. Neurosurgery 1985;17:436-45.

35 Raffel C, Edwards MSB, Davis RL, Ablin AR. Postirradiation cerebellar glioma. Case report. J Neurosurg 1985;63:300-3.

36 Zuccarello M, Sawaya R, deCourten-Myers G. Glioblastoma occurring after radiation therapy for meningioma: case report and review of literature. Neurosurgery 1986;19:114-9.

37 Russell DS, Rubinstein LJ. Pathology of Tumours of the Nervous System. London. Arnold. 1977, ed 4.

38 Iacono RP, Apuzzo ML, Davis RL, Tsai FY. Multiple meningio- mas following radiation therapy for medulloblastoma. J Neurosurg 1981;55:282-6.

39 Spector BD, Perry GS III, Kersey JH. Genetically determined immunodeficiency disease (GDID) and malignancy: report from the immunodeficiency - cancer registry. Clin Immunol Immunopathol 1978;11:12-29.

40 Batzdorf $U$, Malamud N. The problem of multicentric glioma. $J$ Neurosurg 1963;20:122-36.

41 Deen HG, Laws ER. Multiple primary brain tumors of different cell types. Neurosurgery 1981;8:20-5. 